\title{
Connecting the Centre of Belgrade with the Danube and Sava Riverfronts to Increase Attractiveness
}

\author{
Jelena Maric ${ }^{1 *}$, Aleksandra Djukic $^{1}$ \\ ${ }^{1}$ Department for Urbanism, Faculty of Architecture, University of Belgrade, Bulevar Kralja Aleksandra 73, Belgrade, Serbia \\ * Corresponding author, e-mail: jelena.maric1989@yahoo.com
}

Received: 04 January 2018, Accepted: 19 April 2018, Published online: 27 April 2018

\begin{abstract}
Although Belgrade is set on the confluence of two rivers, its riverfronts have never been an integral part of the city, due to the barriers between its historical urban core and the waterfronts. Over the last decade, these areas have come into focus because of their potential for becoming one of the most attractive and important ambient urban environments. In this research, a method for the inclusion of the Sava riverfronts into the urban life of its users was established through an analysis of the quality and intensity of open public spaces and the possibility for improving the pedestrian networks. The area known as Kosančićev Venac has been chosen as a case study, being an important connection between these two sites with its cultural values, tradition and identity. The methods used were observation and content analysis of existing literature, strategies and planning documents. In accordance with a participatory approach, direct surveying of selected stakeholders was developed through interviews and questionnaires and a method of mapping users on social maps. Two main groups of users were included in this research: citizens and tourists. Furthermore, the results were presented in the form of a SWOT analysis showing the main obstacles and barriers, but also the strengths and of open public spaces and a pedestrian network. In conclusion, this paper could serve as a knowledge base for developing future strategies containing specific guidelines for revival and inclusion of riverfront areas, in order for city waterfronts to live up to their full potential.
\end{abstract}

Keywords

city centre, open public space, pedestrian connection, participation, Kosančićev Venac

\section{Background resarch}

Riverfront regeneration and renewal presents one of the best methods for a complete redesign and overall economic, ecological and social redevelopment of urban city areas in many European cities in the 21st century (MacLeod and Craig, 2011). Regarding post-socialist cities, new interest in these areas has arisen with the restoration of the market economy and commercialisation of urban space (Tosics, 2005). Considering the case of Belgrade, which is set on the confluence of two rivers, adequate riverfront regeneration has never taken place, leaving its riverfronts excluded from the urban city centre due to the barriers between its historic core and the waterfronts. Urban redevelopment in Belgrade has a rather spontaneous "bottom-up" nature (such as one in the Savamala district or Beton Hala), lacking the support of governmental or planning institutions (Cvetinovic et al., 2013). In contrast, some other cases like Belgrade port, Marina Dorćol or Kosančićev Venac, considered as the best "polygons" for the redevelopment (Petrović, 2009), have not witnessed any major urban transformation. In the last decade, these areas have been in focus because of their potential for becoming one of the most attractive and important ambient urban environments; this is recognised by users and urban city planners, according to the Master plan of Belgrade 2021. The area called Kosančićev Venac has been chosen as a case study, because of its potential to be developed as an important connection between the urban city centre and the waterfront areas, adding to its values regarding culture, tradition and identity. It is a heterogeneous, mixed-use area connecting the Sava riverfront with the main pedestrian zone, next to the Kalemegdan fortress.

Despite its excellent position and evident potential for revitalisation, this area has been deteriorating for decades, losing some of its inhabitants and failing to attract new ones. Its predominant use is residential, although there are many institutions of education and culture nearby. 
It belongs to rare, well-preserved historical areas with very valuable buildings and open public spaces in Belgrade (Vučenović, 1992). In accordance to this, it is protected as one of just eleven spatial culture-historical zones of extraordinary importance in Serbia (NIPCM, n. d.). Moreover, it has been officially planned as a new tourist area with urban redevelopment (UPIB, 2007); Although it is yet to transformed or redeveloped. The most mentioned reason in professional circles in Serbia is related to financial problems followed by strict protection, private ownership, and the prevalent residential function (Đukić et al., 2015). The research method for the inclusion of the Sava riverfronts into the everyday urban life of its users was established through the analysis of quality factors and the intensity of open public spaces and the possibility for improving the pedestrian network.

\section{Methodology}

The methodology used in this research was developed through different stages, using several methods and tools in combination for location research. Following the theoretical research and with an overall participatory approach, the main research methods included the direct surveying of selected stakeholders developed through interviews and questionnaires. As previously mentioned, the location selected as a case study is the area of Kosančićev Venac, with a special focus on the open public spaces and pedestrian connections. The methodology is divided into several steps: 1 . Content analysis; 2 . Conducting the survey; 3 . Method of observation; 4. Social network analysis; 5. Collecting results.

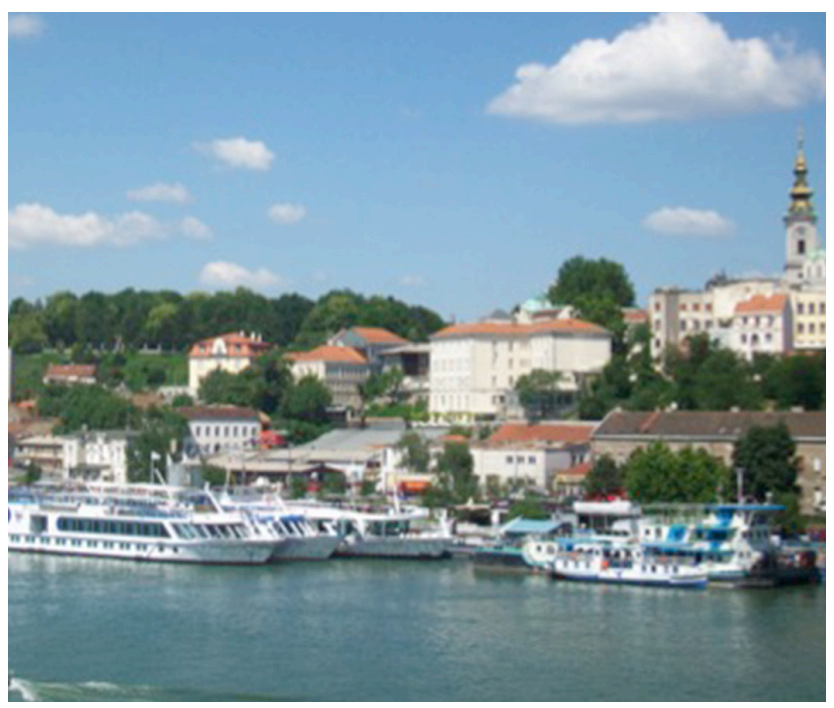

Fig. 1 Image of Kosancicev Venac
Content analysis refers to the theoretical and contextual research of the different documents, studies and planning documents in the background research; these served as a knowledge base for understanding the selected area and developing a concept for the survey, together with the other methods used.

The focus was on the inclusion of actual users of the area. Therefore, stakeholders selected consisted of inhabitants as well as visitors (citizens and tourists). In the collaboration framework and with participation as a goal, the survey is the most important part of this particular methodological process. To gain both quantitative and qualitative data, the survey consisted of interviews and questionnaires. It was conducted in the two months between March and April 2017. A total number of 311 people were included in the survey.

This survey aimed to identify both the problems and potential of the selected area, from a user perspective, regarding various aspects based on the criteria and indicators (C\&I) system. Participants evaluated their level of satisfaction with grades from 1-5 for each indicator.

Criteria for evaluating the location were divided into two categories with nine questions each:

a) QUALITY OF PLACE - comfort, safety, historical heritage, physical appearance of the buildings, greenery, landscape, diversity of activities and urban furniture.

b) MOBILITY AND ACCESSIBILITY - location, public transport, private transport, parking, pedestrian accessibility, pedestrian connections, bike lanes and pavement.

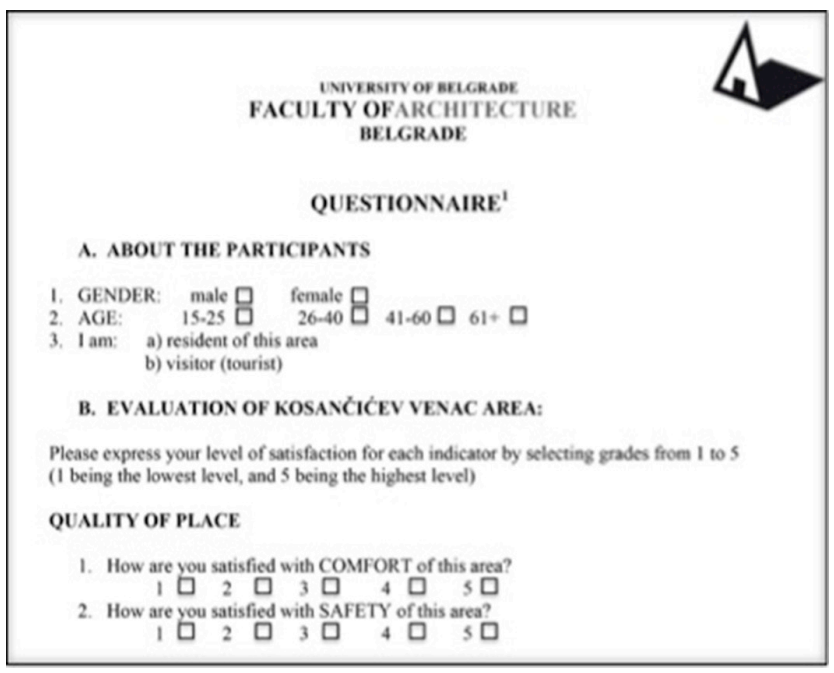

Fig. 2 Sample of the questionnaire used in the survey (Authors J. Marić, A. Đukić) 
Interviews were conducted as a continuation of the questionnaire to clarify and add qualitative information regarding problems and potentials of the area. More than 50 people were interviewed during the study and asked the following questions: What would you consider as the main potentials (strengths and opportunities) of the area, and why; What would you consider as main problems (weaknesses and threats) of the area, and why.

Additionally, user responses overlapped with the method of expert observation. For every day of one week, the authors of this paper measured the intensity of pedestrian movement hourly (in a period from $8 \mathrm{AM}$ until $8 \mathrm{PM}$ ) in six different locations.

Social network analysis was conducted with the focus on the most used mobile application - Instagram. Instagram is a relatively new form of communication where users can easily share their updates by taking photos or videos, adding hashtags to the location. It has seen rapid growth in the number of users as well as uploads since it was launched in October 2010. Although it is the most popular photo capturing and sharing application, it has attracted relatively less attention from the research community. In this paper, we measured the number of users on multiple locations in the area of Kosančićev Venac, by searching through hashtags (Fig. 5). Hashtags are not much different to the "keywords for finding information". The way that hashtags make communications filterable and organised can be put to significant use for getting feedback and suggestions. When tapping on a hashtag, photos with their exact location can be seen. There will be nine top posts followed by all the photos starting from the most recent photo. It is one of the few social media platforms with a Search and Explore tab in its app (Hu et al., 2014).

\section{Results}

This paper aimed to identify the main problems and potentials from the user's perspective and to measure the intensity of pedestrian movement and concentrations of users in open public spaces in the area of Kosančićev Venac and Sava riverfront. Regarding survey results: a total number of 311 people participated, 182 female and 129 male, 45 residents and 266 visitors or tourists, citizens, aged mostly from 15-25 and 26-41. In the table below, results from the questionnaire are presented.

All dimensions are in centimetres as shown in Table 2.

These results show which of the predefined criteria (indicators) are the strongest and the weakest points of this area. Participants are mainly satisfied with location, heritage (culture), and landscape. However, elements regarding public and private transport, mobility, particularly pedestrian accessibility and pavement are perceived as a significant obstacle for using this location as a pedestrian connection between the city centre and riverfront.

Information given in the form of a SWOT analysis presents the summary of all the data gathered through the survey interviews, which are in direct correlation with data gathered through questionnaire analysis.

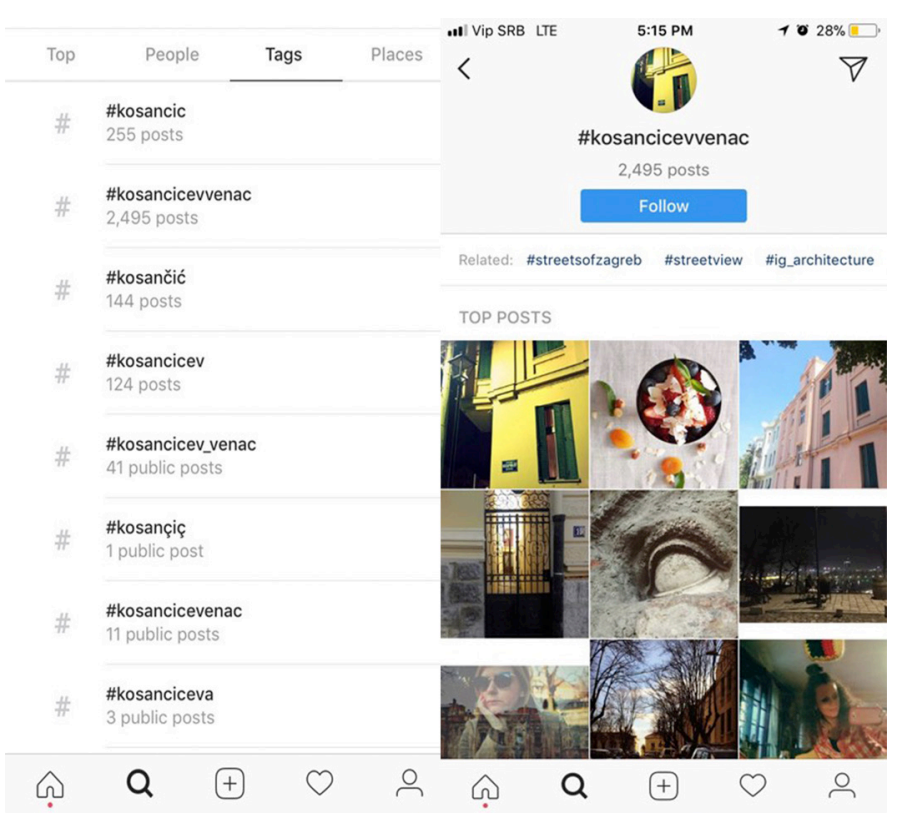

Fig. 3 Instagram search and explore (Authors J. Marić, A. Đukić) 
Table 1 Page margins in centimetres

\begin{tabular}{|c|c|c|c|c|c|c|c|}
\hline \multicolumn{8}{|c|}{ RESIDENTS } \\
\hline & \multirow{3}{*}{ C\&I } & \multicolumn{5}{|c|}{ participants (total 45) } & \multirow{3}{*}{$\begin{array}{c}\text { average } \\
\text { grade }\end{array}$} \\
\hline & & \multicolumn{5}{|c|}{ grade } & \\
\hline & & 1 & 2 & 3 & 4 & 5 & \\
\hline \multicolumn{7}{|c|}{ a) QUALITY OF PLACE } & 3.67 \\
\hline 1 & Comfort & 1 & 11 & 18 & 9 & 6 & 3.17 \\
\hline 2 & Noise & 1 & 1 & 11 & 14 & 18 & 4.04 \\
\hline 3 & Safety & 0 & 0 & 13 & 22 & 10 & 3.93 \\
\hline 4 & Heritage & 0 & 0 & 6 & 11 & 28 & 4.48 \\
\hline 5 & Buildings & 4 & 9 & 17 & 7 & 8 & 3.13 \\
\hline 6 & Greenery & 2 & 2 & 11 & 21 & 9 & 3.73 \\
\hline 7 & Landscape & 0 & 0 & 9 & 15 & 21 & 4.27 \\
\hline 8 & Activity & 12 & 17 & 15 & 5 & 4 & 2.91 \\
\hline 9 & $\begin{array}{l}\text { Urban } \\
\text { furniture }\end{array}$ & 5 & 14 & 15 & 7 & 4 & 2.8 \\
\hline \multicolumn{7}{|c|}{ b) MOBILITY AND ACCESSIBILITY } & 3.01 \\
\hline 1 & Location & 0 & 0 & 3 & 13 & 29 & 4.57 \\
\hline 2 & $\begin{array}{l}\text { Public } \\
\text { transport }\end{array}$ & 11 & 10 & 14 & 5 & 5 & 2.63 \\
\hline 3 & $\begin{array}{l}\text { Private } \\
\text { transport }\end{array}$ & 8 & 12 & 13 & 7 & 5 & 2.75 \\
\hline 4 & Parking & 4 & 7 & 19 & 15 & 0 & 3 \\
\hline 5 & $\begin{array}{l}\text { Pedestrian } \\
\text { accessibility }\end{array}$ & 11 & 14 & 12 & 5 & 3 & 2.44 \\
\hline 6 & $\begin{array}{l}\text { Pedestrian } \\
\text { connection }\end{array}$ & 5 & 14 & 15 & 7 & 4 & 2.8 \\
\hline 7 & Bike lanes & 0 & 4 & 16 & 14 & 9 & 3.57 \\
\hline 8 & Pavement & 11 & 16 & 9 & 6 & 3 & 2.42 \\
\hline 9 & $\begin{array}{l}\text { Terrain } \\
\text { morphology }\end{array}$ & 8 & 8 & 15 & 9 & 5 & 2.89 \\
\hline
\end{tabular}

Results from the table above (Table 3) show intensity of pedestrian movement in selected hours for one week, measured by the number of people passing through the streets mostly used for pedestrian transport through the area of Kosančićev Venac. It shows how the number of people increases during Friday, Saturday and Sunday. By far the majority of people use the riverfront pedestrian path (more than 2000 people per week), making it the street with the highest intensity. Streets with medium intensity (800-1500 people per week) are Karađorđeva Street, Pariska Street and "Velike stepenice" street, while the concentration of pedestrians with the lowest intensity (500-800 people per week) are in the heart of the area "Male stepenice" street and Kosančićev Venac street as seen in the following image.

Social network analysis showed specific locations in the area where the highest number of people were detected.
Table 2 Page margins in centimetres

\begin{tabular}{|c|c|c|c|c|c|c|c|}
\hline \multicolumn{8}{|c|}{ VISITORS } \\
\hline & \multirow{3}{*}{ C\&I } & \multicolumn{5}{|c|}{ participants (total 45) } & \multirow{3}{*}{$\begin{array}{c}\text { average } \\
\text { grade }\end{array}$} \\
\hline & & \multicolumn{5}{|c|}{ grade } & \\
\hline & & 1 & 2 & 3 & 4 & 5 & \\
\hline \multicolumn{7}{|c|}{ a) QUALITY OF PLACE } & 3.65 \\
\hline 1 & Comfort & 18 & 28 & 70 & 67 & 83 & 3.63 \\
\hline 2 & Noise & 7 & 19 & 71 & 78 & 91 & 3.85 \\
\hline 3 & Safety & 21 & 24 & 88 & 75 & 58 & 3.46 \\
\hline 4 & Heritage & 0 & 2 & 41 & 50 & 173 & 4.48 \\
\hline 5 & Buildings & 31 & 60 & 92 & 54 & 29 & 2.96 \\
\hline 6 & Greenery & 25 & 47 & 91 & 58 & 45 & 3.75 \\
\hline 7 & Landscape & 18 & 34 & 87 & 65 & 62 & 4.05 \\
\hline 8 & Activity & 22 & 76 & 51 & 57 & 60 & 3.21 \\
\hline 9 & $\begin{array}{l}\text { Urban } \\
\text { furniture }\end{array}$ & 35 & 88 & 78 & 44 & 21 & 2.73 \\
\hline \multicolumn{7}{|c|}{ b) MOBILITY AND ACCESSIBILITY } & 3.32 \\
\hline 1 & Location & 2 & 5 & 34 & 44 & 181 & 4.49 \\
\hline 2 & $\begin{array}{l}\text { Public } \\
\text { transport }\end{array}$ & 18 & 67 & 63 & 75 & 43 & 3.45 \\
\hline 3 & $\begin{array}{l}\text { Private } \\
\text { transport }\end{array}$ & 26 & 78 & 62 & 63 & 37 & 3.02 \\
\hline 4 & Parking & 25 & 66 & 64 & 68 & 43 & 3.14 \\
\hline 5 & $\begin{array}{l}\text { Pedestrian } \\
\text { accessibility }\end{array}$ & 31 & 80 & 72 & 55 & 28 & 2.88 \\
\hline 6 & $\begin{array}{l}\text { Pedestrian } \\
\text { connection }\end{array}$ & 28 & 85 & 63 & 59 & 31 & 3.44 \\
\hline 7 & Bike lanes & 16 & 34 & 61 & 84 & 71 & 3.6 \\
\hline 8 & Pavement & 41 & 75 & 71 & 47 & 32 & 2.83 \\
\hline 9 & $\begin{array}{l}\text { Terrain } \\
\text { morphology }\end{array}$ & 33 & 73 & 52 & 67 & 41 & 3.03 \\
\hline
\end{tabular}

\section{Discussion and conclusion}

This paper offers detailed information regarding important problems and potential opportunities, as well as pedestrian movement patterns of the location researched.

The methodological steps and presented results show in depth the characteristics regarding the different aspects of the researched area of Kosančićev Venac. The combination of different methods is used with the aim of gaining both quantitative and qualitative information. Although the focus of this particular research was on the participation and level of user satisfaction, to avoid subjective responses in results, methods of expert observation by the authors of the paper were included in this study.

This paper represents valuable research at local level because existing planning documents and projects that target these areas are usually created without the participation of the stakeholders that represent the civil sector. 
Table 3 Page margins in centimetres

\begin{tabular}{|c|c|c|c|}
\hline Place & time & week & total \\
\hline \multirow{4}{*}{$\begin{array}{l}\text { 1. Pariska } \\
\text { street }\end{array}$} & 08:00-09:00 & 159 & \multirow{4}{*}{809} \\
\hline & $12: 00-13: 00$ & 199 & \\
\hline & $15: 00-16: 00$ & 154 & \\
\hline & 19:00-20:00 & 297 & \\
\hline \multirow{4}{*}{$\begin{array}{l}\text { 2. Stairs } \\
\text { "Velike } \\
\text { stepenice" }\end{array}$} & 08:00-09:00 & 79 & \multirow{4}{*}{883} \\
\hline & $12: 00-13: 00$ & 139 & \\
\hline & $15: 00-16: 00$ & 196 & \\
\hline & 19:00-20:00 & 469 & \\
\hline \multirow{4}{*}{$\begin{array}{l}\text { 3. Kosančićev } \\
\text { venac street }\end{array}$} & 08:00-09:00 & 73 & \multirow{4}{*}{550} \\
\hline & $12: 00-13: 00$ & 100 & \\
\hline & $15: 00-16: 00$ & 125 & \\
\hline & $19: 00-20: 00$ & 252 & \\
\hline \multirow{4}{*}{$\begin{array}{l}4 . \\
\text { Karađorđeva } \\
\text { street }\end{array}$} & 08:00-09:00 & 181 & \multirow{4}{*}{1271} \\
\hline & $12: 00-13: 00$ & 200 & \\
\hline & $15: 00-16: 00$ & 364 & \\
\hline & $19: 00-20: 00$ & 526 & \\
\hline \multirow{4}{*}{$\begin{array}{l}\text { 5. Stairs } \\
\text { "Male } \\
\text { Stepenice" }\end{array}$} & 08:00-09:00 & 81 & \multirow{4}{*}{641} \\
\hline & $12: 00-13: 00$ & 147 & \\
\hline & $15: 00-16: 00$ & 183 & \\
\hline & 19:00-20:00 & 230 & \\
\hline \multirow{4}{*}{ 6. Riverfront } & 08:00-09:00 & 379 & \multirow{4}{*}{2086} \\
\hline & $12: 00-13: 00$ & 511 & \\
\hline & $15: 00-16: 00$ & 849 & \\
\hline & $19: 00-20: 00$ & 1196 & \\
\hline
\end{tabular}

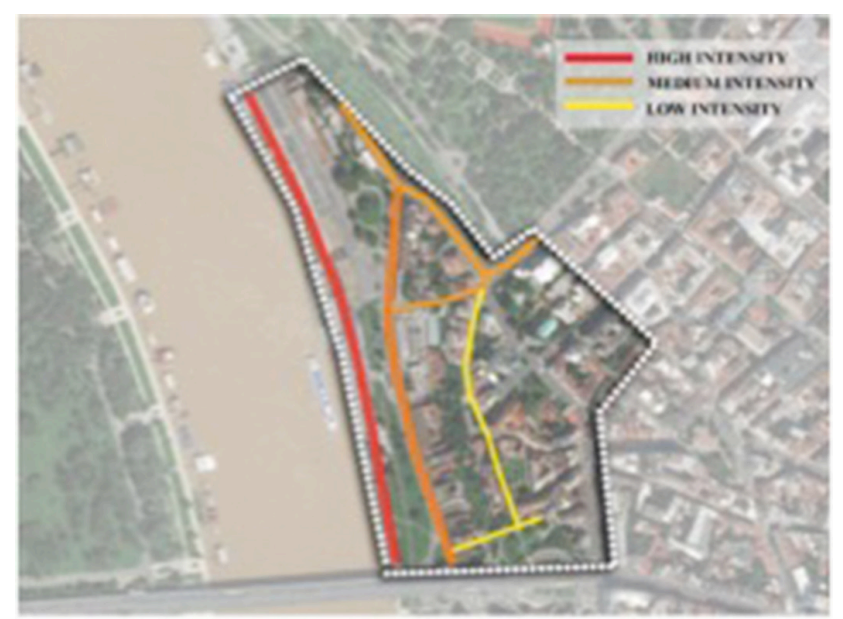

Fig. 4 Results gathered from expert observation method-mapping of the area (Authors J. Marić, A. Đukić)
Table 4 Hashtags (location tags) analysis by number

\begin{tabular}{lc}
\hline Location & Number of tags \\
\hline 01. Beton hala & 9422 \\
02. Church "Saborna crkva" & 2098 \\
03. National library (ruins) & 586 \\
04. Coffee place "Makadam" & 200 \\
05. "Konak Knjeginje Ljubice" & 150 \\
06. Other & 1800 \\
\hline Total number & $\mathbf{1 4 1 0 6}$ \\
\hline
\end{tabular}

Finally, this paper could serve as a knowledge base for developing future strategies containing unique and specific guidelines for revival and activation of Kosančićev Venac and the inclusion of the riverfront area into everyday urban city life.

\section{Acknowledgements}

This paper was completed within National Research Project No 36034, financed by the Ministry of Education and Science of the Republic of Serbia.

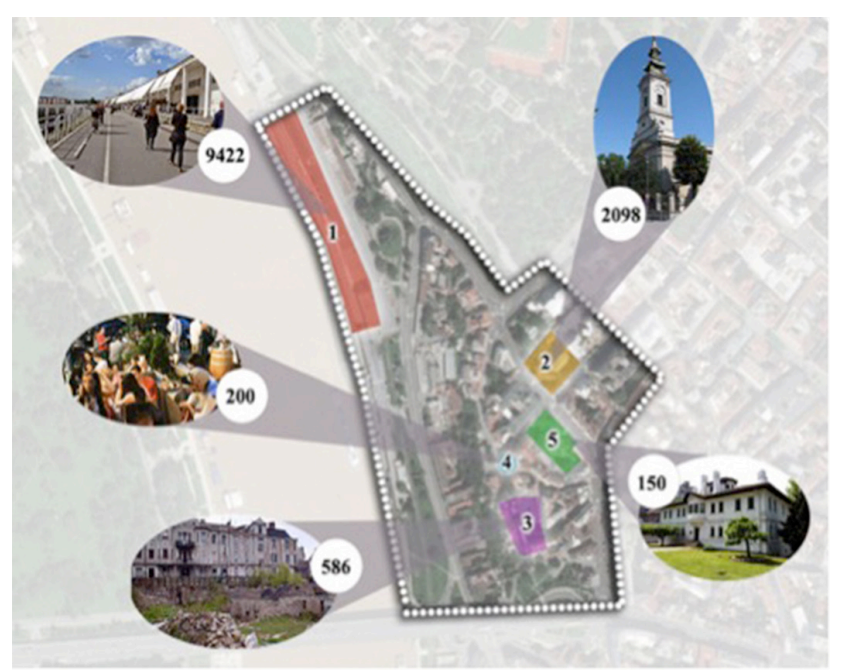

Fig. 5 Results gathered from social network analysis - showing number of users for each location (Authors J. Marić A. Đukić) that explains the significance of the figure 


\section{References}

Bassett, K., Griffiths, R., Smith, I. (2002) "Testing Governance: Partnerships, Planning and Conflict in Waterfront Regeneration", Urban Studies, Taylor \& Francis Group, 39(10), pp. 1757-1775. https://doi.org/10.1080/0042098022000002948

Boyer, M. C. (1994) "The City of Collective Memory, Its Historical Imagery and Architectural Entertainments", The MIT Press, Cambridge, Massachusetts, USA.

https://doi.org/10.1080/13264829609478273

Cvetinovic, M., Kucina, I., Bolay, J.-C. (2013) "Bottom-up Urban Development in Action", In: Savamala Civic District, 49th ISOCARP Congress 2013 of ISOCARP organisation, Brisbane, Australia, pp. 1-14. [online] Available at: http://www.isocarp.net/ Data/case_studies/2408.pdf [Accessed: 03 January 2018].

Đukić, A., Vukmirović, M., Joković, J. (2015) "Connecting places. Smart pedestrian space: network potentials based on user experiences and activities", In: International Scientific Conference: "CITTA 2015 CITTA 8th Annual Conference on Planning Research", in organization of FEUP University of Porto, FCTC University of Coimbra and AESOP-a Thematic Group Public Spaces \& Urban Cultures, Porto, Portugal, pp. 63-79.

Gehl, J. (2010) "Cities for People", Island Press, Washington, USA.

Gordon, E., de Souza e Silva, A. (2011) "Net Locality: Why Location Matters in a Networked World", John Wiley \& Sons, New York, USA.

Hu, Y., Manikonda, L., Kambhampti, S. (2014) "What We Instagram: A First Analysis of Instagram Photo Content and User Types", In: Proceedings of the Eighth International AAAI Conference on Weblogs and Social Media, University of Michigan, USA. [online] Available at: https://www.aaai.org/ocs/index.php/ICWSM/ ICWSM14/paper/viewFile/8118 [Accessed: 03 January 2018].
Lynch, K. (1974) "The Image of the City", The Technology Press \& Harvard University Press, Cambridge, USA. [online] Available at: http://italianstudies.nd.edu/assets/68866/lynch.pdf [Accessed: 03 January 2018].

MacLeod, G., Craig, J. (2011) "Stretching Urban Renaissance: Privatizing Space, Civilizing Place, Summoning “Community”", International Journal of Urban and Regional Research, 36(1), pp. 1-28. https://doi.org/10.1111/j.1468-2427.2011.01067.x

Petrović, M. (2009) "Transformacija gradova: Ka depolitizaciji urbanog pitanja", (City Transformations: Towards Depolitization of an Urban Question) Centar za sociološka istraživanja, Belgrade, Serbia. (in Serbian).

Tosics, I. (2005) "City development in Central and Eastern Europe since 1990: The impacts of internal forces", In: Hamilton, I. F. E., Dimitrovska Andrews, K., Pichler-Milanović, N. (eds.) Transformation of cities in central and Eastern Europe: Towards globalization, UN University Press, Tokyo, Japan, pp. 44-78. [online] Available at: https://chisineu.files.wordpress. com/2012/08/biblioteca_hamilton_transformation.pdf [Accessed: 03 January 2018].

Vaništa Lazarević, E. (2003) "Obnova gradova u novom milenijumu", (Reconstruction of Cities in New Millennium) Classic map studio, Belgrade, Serbia. (in Serbian).

Vučenović, S. (1992) "Урбани развој Косанчићевог венца у Београду", (Urban development of Kosančićev venac in Belgrade) Саопштења (Communications), 24, pp. 143-158. (in Serbian). [online] Available at: http://www.heritage.gov.rs/cirilica/Download/Saopstenja/Saopstenje-XXIV-1992/Saopstenje XXIV_1992_Urbani_razvoj_Kosancicevog_venca_u_Beogradu. pdf [Accessed: 03 January 2018]. 